\title{
Radical Behavior of Students In High School (Study of Social Reality Among KH Abdul Chalim Institute Students, Amanatul Ummah Islamic Boarding School, Pacet, Mojokerto, East Java)
}

\author{
Mauhibur Rokhman $^{1} \quad$ Samsul Wahidin ${ }^{2} \quad$ Dr. Dwi Suharnoko, MS.i ${ }^{3}$
}

\begin{abstract}
The radical behavior of students in Higher Education is one of the interesting phenomena that has been developing for a long time. The fall of the New Order and the fall of Soeharto were the entry points for the radical behavior of students in universities. There is no more control, no more supervision, all currents and ideologies are beginning to flood Indonesia, a sign of being prevented. The pattern of planting radicalism begins with the spread of thoughts that are narrow fanaticism in understanding an event, the values of life and religious understanding. After that, an intensive approach is carried out through mentoring activities, or small groups, until they really believe and believe that what they are doing and their group is the most correct group, and think the other group is wrong or heretical or infidel When this condition has been created, the understanding and cultivation of a more radical understanding will begin to be included, to the point of carrying out a physical radicalism movement which will eventually lead to the emergence of a terrorism movement. Family background, general education and religious education are important variables in shaping radical behavior. Starting from the understandings and thoughts obtained in the immediate environment, namely the family environment, then the school environment and also the relationship of social interaction through extra-campus activities in other academic activities in the form of religious organizations, student movement organizations, and student activity units, student behavior begins to be understanding that is embraced as truth and difficult to change by people who are outside the group. The Islamic struggle movement is identical to the intellectual movement, thus the emergence of radical movements and behavior must be prevented as early as possible. Those who are able to take these preventive actions are the executors at the tertiary institutions, starting from the level of study programs, departments, faculties, to university levels. In this study, the analysis was carried out through a qualitative descriptive approach, by interviewing several key persons from officials within the University and also students who indicated being exposed to radicalism and radical behavior. There are three types of student activity that might be categorized into radical behavior, namely affiliation with KAMMI, HTI and GMNI. If organization such as KAMMI and HTI belong to the right-wing Islamic radical group, GMNI's activities are more likely to be left-wing socialist radicals. With several humanist and psychological approaches, several recommendations and suggestions were generated through this research as an effort to reduce radical understanding in the university environment. One of them is by deepening the material about Islamic religion in the compulsory subject of ahlussunnah wal jama'ah, routine recitation at the faculty and university levels to deepen understanding of religion, education material for state defense and love for the country, as well as other citizenship material that is relevant to the student generally mindset.
\end{abstract}

Keywords: Behavior, Radical, Students, College

DOI: $10.7176 /$ RHSS/11-13-03

Publication date:June $30^{\text {th }} 2021$

\section{Problem Background}

Religious radicalism in recent times has been heavily discussed. Radicalism is an issue that is often associated with Muslim groups. The link between religious radicalism and terrorism is due to the link between the term terrorism and the term jihad, which for decades have become two major issues that are inseparable from each other and characterize the development of the global geopolitical world. Especially after the Bali Bombing tragedy in 2002, all of the perpetrators were Muslims. What was surprising was the incident at the Mobile Brigade Headquarters where several officers from Brimob became victims of violence in their own nests during a riot in the headquarters involving terrorist radicalists in Indonesia.

The link between religious radicalism and terrorism is increasingly visible by referring to the expression of the Head of the National Counterterrorism Agency, Suhardi Alius when he argued about the revision of Law No. 15 of 2003 which aims to eradicate terrorism crimes. According to Alius, the revision of the law needs to be done immediately, because the current exposure to radicalism has penetrated all lines. So, it needs to be

\footnotetext{
${ }^{1}$ Doctoral Candidate In Social Sciences Postgraduate Program at Merdeka University Malang

${ }^{2}$ Professor Of Social Science Doctoral Program At the Postgraduate Program Merdeka University

${ }^{3}$ Prospective professor of Social Science Doctoral Program at the Postgraduate Program at Merdeka University Malang
} 
prevented immediately. As a result, religious radicalism is seen as a matter that threatens security, even the unity of the state which must be anticipated for its existence, as has been done by the government through Government Regulation in Lieu of Law (Perpu) Number 1 of 2002 concerning Eradication of Criminal Acts of Terrorism and Government Regulation Number 2 of 2002 concerning Enforcement of Regulation Government in Lieu of Law of the Republic of Indonesia. Government Regulation in Lieu of Law no. 1 of 2001 was later stipulated as Law No. 15 of 2003

In another development, in 2010 the government issued Presidential Decree no. 46 of 2010 concerning the establishment of the National Counter-Terrorism Agency (BNPT) as a development of the Coordination Desk for Combating Terrorism (DKPT) which was formed in 2002. The Coordination Desk for Combating Terrorism stipulates the merger between the Anti-Terrorism Unit of the Indonesian National Police and the three anti-terror organizations of the armed forces and intelligence, then merged into the National Police Unit. Anti-Terror Task. In 2003, Law Number 15 of 2003 concerning Criminal Acts of Terrorism was enacted (Anti-Terrorism Law). This law emphasizes the authority of the National Police as the main element in eradicating criminal acts of terrorism. In line with this, the Chief of the National Police Decree No. 30/VI/2003 dated 20 June 2003 was issued which became the basis for the establishment of the National Police's Special Anti-Terror Datasemen 88, or better known as the Police Densus 88 AT. Densus 88 which later became an elite unit in countering terrorism in Indonesia.

Through the Counter-Terrorism Agency, religious radicalism is being intensified as contained in one of the five main missions of the National Counter-Terrorism Agency, namely, deradicalizing and fighting radical ideological propaganda. Then, the mission was revealed to be one of the functions of BNPT, namely, the implementation of deradicalization. Not only the government and its apparatus (Polri and TNI), academics also pay attention to religious radicalism through research programs. The adventure of searching for the roots of religious radicalism begins, as in a a research report by Ahmad Rizky Mardhatillah Umar entitled Tracing the Roots of Islamic Radicalism in Indonesia in the Journal of Social and Political Science Volume 14, Number 2 , 2010. This research in addition to tracing the roots of Islamic radicalism in Indonesia, also tries to read its relation to terrorism. As a result, the conclusion that can be drawn is that radicalism in Indonesia is rooted in the existence of gaps in society.

This gap was addressed with radical and militaristic steps by the Political Islam Group. Meanwhile, on a structural basis, it can be seen that there is an elite oligarchy that controls political and economic resources. Thus, creating marginalized and structurally impoverished groups. At the end of his conclusion, Umar emphasized that the issue of religious radicalism/Islamic radicalism cannot be separated from the state's efforts to eradicate poverty. Umar came to the conclusion that there are two things that we can read as the cause of radicalism, one of which refers to the fact of poverty as an indicator of the political-economic aspect. In addition to political oppression, there are signs of economic-political oppression.

With this argument, radicalism arises because of the excesses of capitalism that create those who do not have access to capital sources. In the language of political economy, this approach is known as the "class approach". That is, the response of radicalism is basically a class response to fight the oligarchic hegemony of capital with the state. Thus, radicalism is read as a portrait of historical consciousness combined with class consciousness. This article will elaborate on these two arguments as a tool to trace the roots of Islamic radicalism in Indonesia.

The "hunt" for religious radicalism was also carried out among students, which in the end concluded that one of the factors for the spread of Islamic radical groups among students was inseparable from the efforts to regenerate intellectual groups among Islamic fundamentalists. Meanwhile, the strategy used by "radical groups" is ideological indoctrination which makes it difficult for students to separate from their groups. The radicalization process apparently also reached campuses, especially among students.

One of the evidences is the arrest of five of the seventeen members of the Pepi Fernando network with a bachelor's degree, three of whom are graduates of the Syarif Hidayatullah State Islamic University (UIN) Jakarta. Previously, students of the Faculty of Science and Technology UIN Syarif Hidayatullah were also involved in acts of terrorism which were successfully neutralized by the Special Detachment (Densus) 88 Anti-Terror Police Headquarters. This is surprising because the university's rector is often invited to speak about pluralism and the peaceful teachings of Islam. This raises a question that is quite interesting because UIN Syarif Hidayatullah Jakarta is known to be liberal, but it turns out to be wrong.

Many analyzes so far have stated that the recruitment of radical networks among students is usually aimed at general universities and more specifically students in exact science faculties. In other words, most of the students recruited were from a background of minimal religious knowledge. That way they are easier to indoctrinate. Based on a research report conducted by the Research and Development Department of the Ministry of Religion in 1996 at four secular universities namely UI, UGM, Unair and Unhas, there was an increase in religious activities in a number of universities.

These campuses, it is even stated that these campuses are the most potential places for the development of 
Islamic (religious) activities that tend to be exclusive and radical. Thus, Islamic revivalism does not arise from religious-based campuses, but from secular or public campuses.

The academics' intentionality towards religious radicalism is not only aimed at students, NGOs such as the Islamic Defenders Front (FPI), by placing religious radicalism on its status as deviant behavior, but also seeing pesantren as a production base for radical teachings and even being called a producer of militant cadres for the emergence of radicalism. . The results found that FPI is a sub-culture deviance group that commits acts that violate legal norms that apply in society. By referring to the Criminal Code, it is concluded that FPI's actions deviate from the values generally accepted in society.

The deconstruction of the interpretation of the verses of the Holy Quran and several books that are taught are also allegedly a source of motivation for religious radicalism. Because the verses and contents of certain books about jihad-as a source of the noble values of the struggle-sourced from the texts in the Qur'an and the teachings in the books being taught. Deconstruction of interpretation needs to be done with the aim of straightening out the "wrong" understanding of God's word. Not only the deconstruction of interpretation, Muslim academics also try to explore the concepts of Muslim thinkers, such as the concept of makrifat Al Ghazali and Ibn Arabi, with assumptions, can be an anticipatory solution to religious radicalism.

Children and adolescents also get a share in the intentionalization of religious radicalism through the preparation of a multiculturalism education-based counseling guidance program. Seeing that children and youth are the next generation so they must be protected with proper handling. The psychological state of children and adolescents is always pursued in multicultural education, namely by forming an interfaith community that will be used as a world of play for children and a relaxed atmosphere for teenagers. As a result, from the constellation of government work, law and academia, a national program was drawn up in order to "tame" and anticipate people who had been declared exposed to radicalism, as well as people who were declared free/not exposed to such exposure.

Radicalism, with reference to its understanding of the spirit of upholding Islamic law, has actually emerged in the public sphere when the Indonesian State was first established. During the New Order era, radical thinking was interpreted as anti-government which also meant anti-Pancasila. If you look at the current phenomenon, radicalism has significantly shifted, from an attitude against the government which also meant rejecting Pancasila during the New Order era - which was actually an attitude of resistance to an authoritarian government - to an attitude that was disturbing and disrupted stability, security and unity. Moreover, radicalism is often interpreted as an anti-Western attitude that wants to uphold Islamic values and has ties to Al Qaeda.

This is the main attraction to see religious radicalism as a discourse that is able to influence human behavior at a certain place and time; such as the declaration of anti-radicalism made by the Santri. More than seeing religious radicalism as a social phenomenon, By using Michel Foucault's genealogical theory of power, this study tries to see the genealogical network that builds the discourse of religious radicalism in Indonesia which actually places religion as an important element in its constitution. The search for the genealogy of discourse itself is nothing but a search for the genealogy of power. That is, power can only be seen when it realizes the consequences that indicate a dominated position.

In the context of this study and research, religious radicalism has existed in Indonesia since Natsir released the Islamic Da'wah Council (DDI) in 1967 by uniting political and da'wah movements. This Masyumi-scented movement continues to roll by reducing the thoughts of Hasan al-Bana, Sayid Quthub and Sa'id Hawa, which were originally non-revolutionary but laden with Salafi nuances.

Entering further into the research context, preliminary observations have been made and show the interesting and urgent side, namely the assumption of the seeds of radicalism among santri and students of the Amanatul Ummah Islamic Boarding School, Mojokerto. Although the indications are vague, they can be felt from the political attitudes and behavior of students who tend to act radically. This landmark can be felt considering that researchers are used to seeing their attitudes and behavior, even their confrontational actions towards the teachings of religious rituals that are commonly attached to the Nahdhiyin residents as the majority of the community in the study area. Most of the Javanese people who are oriented to the Sunnis often have to deal with the attitude of some students who are not good enough. They did not hesitate to make accusations of heresy and superstition to most of the 'amaliyah of the Nahdliyyin. The opposite attitude does not care if it is directed at anyone, even though it is still considered a relative or relative. The seeds of this confrontation began to spread since the arrival of KH Abdul Chalim Institute students from all over the archipelago.

Such confrontations still occur today, when the state begins to supervise and foster religious sects that are destructive to social life. The guidance that has been carried out has turned out to be less effective in the context of preventing this kind of radicalism. This urgency is an urgent side for a research that will be able to provide at least an identification of the root of the problem and even a targeted solution if necessary. And it is common among adherents of radicalism, Central Java seems to be the mecca for the growth of radicals which of course disturbs the people who have lived in the area for so long living in harmonious conditions. The vortex of noise is becoming increasingly prominent in this region and has even penetrated to some areas of Java and outside Java 
as excesses of radicals that are voiced and transmitted to become a common problem for the integrity of the nation and the Unitary Republic of Indonesia.

Content that often echoes the term heresy as a characteristic of their movement against outsiders who are not in line and in line, both in thought and movement. The heretical jargon that is addressed to Muslims outside of their principles actually makes the radicals increasingly portray a tough character which they themselves claim is puristic or purification of understanding. This kind of understanding is interesting to be studied thoroughly and of course needs to be approached from the perspective of social behavior in society or in certain groups, where the study of social behavior as a perspective in Social science is a point of view or approach that is used as a tool for explaining complex concepts or theories.

In fact, this research needs to be done because there is so much radicalism and behavior in universities, even in universities with religious education backgrounds, it is not free from the inclusion of radicalism in the campus environment. There needs to be prevention efforts, at every level, every campus institution, can make strategic efforts so that radical behavior can be prevented and minimized as early as possible.

\section{Theory of Social Behavior and Radical Behavior}

Social behavior is an atmosphere of interdependence which is a must to ensure the existence of human Abraham (2001). As proof that humans in fulfilling the needs of life as individuals cannot do it alone but need help from others. Humans as social beings mean humans as creatures who have a dimension of togetherness with other people around them. Psychoanalytic theory states that humans have social moral considerations (super ego) when faced with the choice of social behavior. While the humanities explain social reality as a living organism in the form of social theories about human life in the form of society.

According to psychosocial theory and cognitive development theory, it states that the behavior that exists in a person is based on cognitive moral considerations. Furthermore, the problems of rules, norms, values, ethics, morals and aesthetics are things that are often heard and are always associated with moral concepts when someone will make a behavioral decision. According to Krech, Crutchfield \& Ballachey (1982) a person's social behavior is shown in the pattern of responses between individuals expressed by inter-personal reciprocity. Social behavior is also synonymous with a person's reaction to others Baron, R.A. and Byrne, D. (2005).

The behavior is indicated by feelings, actions, attitudes, memories and respect for others. A person's social behavior is a relative trait to respond to other people in different ways. In fact, the basis for the description above is that humans are essentially social creatures (Gerungan, 1986) this is because if there is no reciprocity from social interaction, humans do not realize their potentials as complete human beings and individuals as a result of social interaction. When socializing, what is shown is social behavior. The formation of a person's social behavior is influenced by various internal and external factors. In the external aspect, the social situation plays an important role. Social situation is defined as any situation in which there is a mutual relationship between humans with one another (Gerungan, 1986). In other words, any situation that causes social interaction can be said to be a social situation.

Examples of social situations, for example, in a market environment, at a meeting, or in a physical education learning environment. According to Arthur S. Rober, a professor of psychology at Brooklyn College, University of New York City in Muhibbin (2000) states that behavior or behavior is a a very general term encompassing any action, activity, response, reaction, movement, process, operation or response of an organism that can be measured. According to Zimmerman and Schank (2013), behavior is an individual's effort to selfregulate, select and utilize as well as create an environment that supports their activities. Individuals select, organize and create a balanced social and physical environment to optimize the achievement of the activities carried out. According to Lawrence Erlbaum (1989), behavior is a generally observable muscle activity or external excretory glands that is manifested, for example, in the movements of body parts or the appearance of tears, sweat, saliva and so on. Behavior is the real basis of psychology and we don't include it in any sense that is likely to be less observable. A person's behavior is driven by motivation. At this point, motivation becomes the driving force of behavior (the energizer) as well as a determinant of behavior. Motivation can also be said as a theoretical construct regarding the occurrence of behavior.

Behavior is also the result of the interaction between personality characteristics and social conditions as well as environmental physical conditions. The term social has different meanings according to its usage. The term social in social science refers to its object, namely society. In addition, social is concerned with individual interpersonal behavior, or relating to social processes.

The form and social behavior of a person can be shown by his social attitude. Attitude according to Akyas Azhari (2004) is a way of reacting to a certain stimulus. While the form of social attitude is expressed by the same and repeated way of activities against social objects which causes the behavior to be expressed repeatedly towards one of the social objects. Islam balances personal rights, the rights of others and the rights of society, so that there is no conflict. Instinctively, by nature or by nature, humans need other people in their lives, so humans are born all need the instinct to communicate with their mothers, to be able to survive asking for protection and 
food assistance. By nature, it means that God created it. Humans are social creatures, namely creatures who need each other for growth and development, and without each other humans would not be human. Regarding how the relationship between individuals in the wider community should be, namely the pattern or process of relationships that can lead to happiness in the world and the hereafter for all individuals involved, Islam conceptualizes that life must be based on the social behavior of the community as follows:

\section{a. Respect others}

Of course, in living this wheel of life, there are many differences, both from a person's perspective, personality and others. For this reason, an attitude of respect for others is needed in order to create a harmony in the association and in society. Abdusshomad, M (1993) states that respecting others is a behavior in which a person can place himself in his atmosphere or environment when faced with various differences. Mutual respect has many benefits in association. Not only guarantee comfort in socializing, this attitude of respect will also return to oneself. Whoever respects others, indeed they are honoring themselves must cooperate in developing the laws of Allah.

\section{b. Mutual help}

According to Abdusshomad, M, (1993) can explain that in living this life, every human being must have experienced both ease and difficulty. Sometimes there are happy moments to fill life. But at other times, misery greets the unexpected. In such difficult circumstances, a person needs a helping hand to lighten the burden that befell him. Helping is something that every human being must do, because basically humans are social creatures who cannot live alone. Islam commands its people to help each other and help each other without discriminating against class, because by helping each other can lighten the burden of others. If from an early age a child is accustomed to helping each other, then in adulthood they will get used to helping each other.

\section{c. Politeness}

Modesty here refers to the willingness of the physical ability or the tendency of the mind to maintain attitudes, ways and things that are considered appropriate and good in the eyes of society. Through how to dress, behave, behave, look, and others. Alfred, John and James Julian M. (2008) argue that a polite person tries to be polite does not mean that person always has to say yes to others. Politeness also doesn't have to mean one has to please the other party all the time. So politeness is an attitude of humility in speaking, behaving in everyday life. On the other hand, politeness is also needed as a tool to show rejection without showing disapproval.

\section{Factors for the Formation of Social Behavior}

Baron, R.A. and Byrne, D. (2005) argue that there are four main categories that can shape a person's social behavior, namely:

a. Behavior and Character of others. If a person often hangs out with people who have a polite character, there is a high possibility that he is familiar with behaving like most people who are polite in his social environment. Conversely, if you hang out with people with arrogant character, then he will be affected by such behavior.

b. Cognitive processes. Memories that contain ideas, beliefs and considerations that form the basis of a person's social awareness will affect his social behavior. For example, a prospective coach who continues to think that in the future he will become a good coach, become an idol for his athletes and others will continue to strive and process to develop and improve himself in his social behavior.

c. Environmental factor. The natural environment can sometimes affect a person's social behavior, for example, people who come from coastal or mountainous areas who are used to speaking loudly, then their social behavior seems hard too, when they are in a community environment that is used to being soft and smooth in speaking.

d. The cultural setting as a place for social behavior and thought that occurs, for example, someone who comes from a certain ethnic culture may feel strange social behavior when in a community of another ethnicity or different.

In the context of student behavior in tertiary institutions, the Amanatul Ummah Islamic Boarding School environment, Pacet, Mojokerto, where according to Fritz Heider (1983) social behavior in humans can be caused by internal factors called internal attributions or can be caused by external factors called external attributions. . A person's existence can be known both from his physical appearance, thoughts, and motives as well as from the behavior displayed by the person concerned (over action). According to Deswita (2006) humans are the most perfect living creatures compared to other living things. Because humans have reason as a differentiator and is an ability that is more than other creatures. As a result of this ability, humans experience development and changes both psychologically and physiologically.

Changes that occur in humans will cause changes in human personal development or behavior. The formation of behavior cannot occur by itself or without a process. However, its formation always takes place in human interaction, and is concerned with certain objects, according to Baron \& Byrne (2005) and Krech, Crutchfield \& Ballachey (1982) social behavior is relative to responding to other people in different ways. While 
the factors that shape the behavior of political sociology in the moderation of religious power, which exist in people's lives and affect the patterns of life that exist in society. This has become a very important object of study in political sociology, considering that all segments of human life require politics. Even from birth until the time of his death to expand the power of recognition, politics is needed.

The first behavior emphasizes the importance of consensus or compromise. While the second behavior tends to lead to conflict" in relation to this approach, Deliar Noer (1983) suggests that broadly speaking, political scientists have used two kinds of approaches, namely an approach that emphasizes values and an approach that emphasizes behavior. So the researcher can conclude that the factors of social behavior are a strategy as a foothold to find out the maintenance of relationships in a deeper society, so that various problems related to the phenomenon of social behavior and radical behavior of students in higher education institutions can be revealed more thoroughly. There are two main factors that can influence a person's social behavior, including:

\section{A. Driving Factors}

Internal factors according to Jalaluddin Rakhmat, (2008) are factors that are contained in humans themselves or everything that has been under the control of children. from birth, namely the holy nature which is an innate talent. Human social behavior can be influenced by several factors, namely as follows.

1) Intellectual Intelligence, in human social behavior plays an important role in influencing social behavior in society. Therefore, emotional intelligence is often referred to as social intelligence which in practice always carefully considers all the social aspects that accompany it. In social behavior, emotional intelligence plays a very important role. The existence of empathy, motivating others and fostering relationships with others are the most important aspects of emotional intelligence and become an inseparable part of other factors that influence a person's social behavior in society (Saleh, AR, 2009). Intellectual intelligence plays an important role in influencing a person's social behavior in many societies. Memories and thoughts that contain ideas, beliefs and considerations that form the basis of a person's social awareness that will affect his social behavior. Science is an essential factor in education. The involvement of human science in solving various social problems that greatly affect the quality of morals and character. On the other hand, if uncontrolled, these noble values can cause self-defeat. Humans believe that their behavior is not based on emotional idiosyncrasies but on intellectual factors that induce self-control activities that excel in their function in response to emotional stimuli. It is true that many human responses are directed by objective reasoning and judgment, but there are times in the lives of most human beings when emotional impulses and almost completely influence human thinking and behavior. Too often, human behavior is intimately linked to the emotions imparted to human beings in more basic and broad activities. Emotional must influence behavior but does not have to be a self-determination, (Saleh, 2012).

2) Motivation, based on the theory of needs according to A, Maslow (1970) the meaning of motivation is a reason that underlies an action carried out by an individual. Someone said to have high motivation can have a very strong reason to achieve what he wants by doing his current job. So, it should be understood that there are differences in the use of the term motivation in society. There are those who interpret innovation as a reason, and there are also those who interpret motivation as the same as enthusiasm. Motivation is a driving force that generates activity in living things and will cause behavior and direct it towards certain goals. According to Saleh. M (2012) provides a statement in this case motivation plays its role as a person's reason for doing something. Motivation is the urge to do something. In social behavior, this motivation is important, because a person's social behavior is a motivated behavior. 1. Religion, Taufiq Muhammad Izzuddin (2006) suggests that religion plays an important role in influencing a person's social behavior. A person who has a broad understanding of religion, must also have good social behavior. Because in essence, every religion teaches goodness, especially Islam, strongly encourages its people to have social behavior.

\section{B. Inhibiting Factors}

The external factors referred to in this study are everything that exists outside of humans, which can affect the development of personality and religion outside of a person. Religious behavior is part of a person's religion. So the factors that influence religious behavior can not be separated from the experience factor outside the person. The external factors are as follows.

a) The family environment is the first and foremost environment. It is in the family that humans find their nature as social beings. Because in the family environment for the first time interacting with other people. Domestic life is full of dynamics of events. From there children get their tendencies and emotions. If the home climate is full of love, affection, calm and determination, then the child will feel safe and confident in the family, so that stability and steadfastness and essentialness in the family appear in itself. But if the home atmosphere is full of conflicts and chaotic violent relationships between family members, it is reflected in the child's behavior, so that chaos and indecision appear in the behavior of his own child. His adaptation to himself and to members of society is bad in any situation.

b) The community environment, according to Abdusshomad (1993), society is a place for living together from individuals who are intertwined and bound in social interactions and interrelationships. In human life in 
society there is always a match between individuals through the process of socialization towards relationships that influence each other's environment, which is no less important in shaping the child's personality, because in society various social, cultural, economic, religious and other organizations develop. The development of social behavior greatly affects the direction of the development of children's lives, especially those concerning social attitudes and behavior. The behavior of children or adolescents is a reflection of the behavior of the community environment. Therefore, the quality of the development of behavior and social awareness of children is very dependent on the quality of social behavior of its citizens. Social behavior is formed from the social interactions experienced by individuals. Thus it is better if you are more careful in choosing the environment. Parents, teachers, and community leaders should also be careful in creating a good social environment for the development of each individual.

To judge people and their behavior ethically, it is not enough to consider only external stimuli or internal factors. To assess people and their behavior in a complete, adequate and balanced, it is not enough just to be based on the internal factors that drive the person's life and behavior. The assumption is that the world is as experienced by the Indonesian people who always say hate speech, Jones, (2009). Microsociology theorists pay less attention to the social disadvantages of society, when discussing microsociology as humans who interact socially. Social behavior reflects an atmosphere of interdependence which is a must to ensure human existence, Rusli Ibrahim, (2001).

For this reason, humans are required to be able to work together, respect each other, not interfere with the rights of others, be tolerant in social life. The two main microsociological theories of interactionalism begin with propositions that are central to any theoretical analysis of social identity. Deviant behavior is defined as a person's behavior, actions or responses to the environment that are contrary to the norms and laws that exist in society, deviant behavior tends to like trying new things, in the sense that they are still looking for their identity, preferring to be in groups or forming groups rather than being alone. . The lack of control of the child is the same as that experienced by children from which families, parents and children who do not live at home or live far apart will cause emotional relationships that are no longer well established and closeness is reduced due to strained relationships. This condition can also occur where even though parents live with their children in the same house, the busyness of parents can also cause an emotionally tenuous relationship.

According to Abdulsyani, and Hasan Sadilhy (1994) say that humans are social creatures, will be interested in living together in society, namely the desire factor, the weakness factor, and the human factor. The factors that always encourage people's social behavior can be described as follows.

a. The desire that is based on the instinct of a biological will that is beyond the control of reason to find a mate, firstly to fulfill sexual needs that are biological in nature as found in all living things.

b. Human weakness always urges to seek common strengths, which are found in association with others, so that they can take refuge together and can meet the needs of daily life with joint efforts. Aristotle argues that humans are zoon politicons, namely social creatures who only like to live together, preferring to live alone.

c. According to Bergson, H., et al, (2007) that these humans live together not because of similarities, but because of differences in nature, position and so on. He said that the new reality of life was felt by the differences between each human being in group life.

\section{Findings and Propositions of Understanding Radicalism in Amanatul Ummah Islamic Boarding Schools and Islamic Boarding Schools}

Some important things that can be concluded as major propositions based on the group of questions about; (1) learning methods and curricula in Islamic boarding schools and tertiary institutions, (2) methods of recruiting teachers, ustadz and lecturers, (3) non-academic learning (extra curricular), (4) targeting graduates from the institutions they lead, (5) tracking whereabouts graduates and the participation of alumni in Islamic boarding schools, and (6) the background of radicalism in Islamic boarding schools and universities. The findings that we can conclude in universities and in this case are the KH Abdul Chalim Institute, Pacet, Mojokerto, the findings are as follows;

Findings 1. The learning method at the KH Abdul Chalim Institute refers to the curriculum nomenclature from DIKTIS, from the Ministry of Religion.

Finding 2. The method of recruiting lecturers is done online and according to the needs of the lecturers or teaching staff in each study program. The recruitment pattern is independent and does not involve the Amanatul Ummah Foundation team at all.

Finding 3. Non-academic learning is quite diverse, starting from Banjari, Scouts, Pencak Silat and internal campus organizations such as student associations for study programs and regional student associations. Other student organizations include PMII, IPPNU, and PERGUNU.

Minor 1 proposition that the curriculum and learning methods at IHKAC close the opportunity for radicalism to enter campus. Likewise with non-academic activities controlled by the Foundation, thereby minimizing the 
potential for radicalism to enter campus.

Finding 4. The target of graduates is in accordance with the direction of the Caretaker of the Islamic Boarding School, but so far the target of S1 graduates is to be able to work professionally according to the scientific field pursued while studying at IHKAC

Finding 5. Tracking alumni through the website and google form, can be found on the official site of the IHKAC campus.

Minor Proposition 2 The target of graduates is very normative and oriented to graduate achievement, with strict alumni tracking to find out the latest conditions of alumni.

Finding 6 . The notion of radicalism has very wide opportunities at the IHKAC campus, this is because the new students enrolled at IHKAC are very diverse and come from all provinces in Indonesia, both for undergraduate and postgraduate levels.

Minor Proposition 3 With the diversity of prospective students, especially scholarship students representing each province, it is necessary to have a filter in the form of regulations and policies so that prospective new students are not exposed to radical ideas that may be brought from outside the pesantren.

Major Proposition 1. The KH Abdul Chalim Institute (IKHAC) which is located within the Amanatul Ummah Islamic Boarding School does not provide opportunities for radical understanding to enter through strengthening academic and non-academic curricula. academic, rigorous recruitment of teachers, strengthening of the target of graduates and tracking of alumni.

Regarding the phenomenon of radicalism among students, it is true, something that can be grasped and learned, although basically this kind of movement uses a visible cell system, it is like the wind that can be felt but difficult to hold. Students who are recruited into radical movements do not only come from general (secular) universities, especially those from the exact faculty, the latest developments inform that religious-based campuses are also not spared the target of recruiting radical movements. There are two reasons why the radical movement among students occurred; First, there has been a change in religious-based universities in the campus environment. Second, there has been a metamorphosis of the form and strategy of the movement in the internal radical movements in the campus environment.

The results of interviews with several student informants related to the radical behavior of students in higher education revealed some very interesting facts to be studied in more depth. Some of the questions given to key informants from students were divided into two groups, namely, internal factors from the family; family educational background, level of economic welfare, individual education level, social status and family social activities, then external factors; organization, study and social interaction followed by both individuals and families, ideas and concepts of struggle, and others. For discussions related to exposed students, they will be divided into several groups, namely KAMMI cadres at S1, KAMMI cadres at S2 level, HTI cadres, and GMNI cadres.

Economic background is often the reason for the limited financial capacity of a person or group of people. Students exposed to almost all come from families belonging to the economically weak. Being poor or financially weak is indeed one of the easiest gaps for radical understanding to enter among students. They need attention, need support, especially those who can help them financially. It is known that some of the informants are scholarship students sent by their regions to study at the $\mathrm{KH}$ Abdul Chalim Institute. It is known here that economic factors are often the reason for the limited financial capacity of a person or group of people. The weak economy also has an impact on the desire to get financial assistance through activities that are participated in by the students concerned.

An individual's social status to be recognized is also a trigger for a student to take an attitude and act whose real purpose is only to seek identity, identity, and recognition within the group and community as well as in society at large. Individual social status to be recognized is one of the reasons a student is active in campus activities.

However, sometimes they are not aware that structured recruitment activities in campus organizations, especially to be active in certain activities on campus, have certain targets, especially in terms of conveying ideas that tend to be radical. In order for these activities to run well, there are times when they take cover under the auspices of the campus mosque takmir organization. However, in IHKAC, what often happens is that they take refuge under regional organizations which in each of their regular meetings not only discuss kinship on the basis of regional similarities but also convey certain doctrines that lead to radical ideas and of course have an impact on behavior. radical students in Islamic boarding schools.

Finding 7. Economic factors are one of the triggers for student radical behavior to occur easily in the university environment.

Finding 8. Social attitudes to be recognized, play a role and contribute to students' radical behavior through unguided religious activities in the university environment.

Minor Proposition 4. Students who are exposed to radicalism really expect financial support and emotional 
attention. Social activities that create a feeling of self-confidence, play a role in religion, and contribute to the struggle for the movement for the glory of religion, are also part of the doctrine conveyed to students.

The limitations of religious education, minimal and limited understanding of religion can have an impact on the low ability to filter information that has just been received by a student. Two of the postgraduate student informants also did not have an educational background in a pesantren. They gain an understanding of religion during their undergraduate education in their area, through religious activities at the previous campus. With a non-Islamic boarding school education background, they automatically only get religious education from schools and their neighborhoods. The lack of religious knowledge has an impact on the weakness of universal and partial religious understanding. They find it difficult to distinguish this understanding of religion or political doctrine under the guise of religion. The limitations of religious education, and the lack of understanding of religion can have an impact on the low ability to filter information that has just been received by a student.

Becoming the administrator of a mosque organization is one option, and it turns out that on campus there are often organizations within the organization. This is like a covert activity carried out by students. Confusion, ambiguity, uncertainty of activities, whether the activities are purely mosque activities or campus mosque activities that are ridden by certain organizations, can happen like that.

Structured recruitment in campus organizations, this recruitment has actually started since I was in high school. The method used is of course using an extension of high school alumni who are in college, then they take part in religious events in high school under the pretext of religious guidance. A student of the Faculty of Economics, but being a teacher in a high school environment is a slightly ridiculous phenomenon, not only related to the competence of a teacher who is only a student, but about what material they will convey even though in terms of religious understanding, of course, it is still very shallow and only on the surface. Taking refuge under the auspices of the campus mosque takmir organization, is one way to make their movement 'legal' even though what they do sometimes has absolutely nothing to do with campus mosque takmir activities.

Students only follow the cadre flow given by seniors whose activities are related to the activities of the mosque's takmir organization.

Finding 9. The limitations of religious knowledge have a direct impact on the ease with which radical understanding enters students' minds without any filter.

Finding 10. Want to be recognized socially by the environment and society through religious activities on campus.

Finding 11. Religious organizations on campus are infiltrated by activities wrapped in religious activities, even though they have absolutely no relevance to campus religious activities unless they are radical doctrinal activities.

Minor Proposition 5. The limitations of religious knowledge, the desire to be socially recognized often make student activists choose the wrong place to channel their organizational desires.

The concept of studies and Islamic cadre materials, in general, have similarities with the material they received when they were still in high school or taking undergraduate education. The deepening of the material which then the responsibilities they receive increases when they become seniors. One of their responsibilities is to replace other seniors in the process of transferring knowledge to their juniors. It seems that this is a structured religious learning error, because they learn from sources who are not experts in the field of religious knowledge, and it happens continuously, passed on to their juniors. Through structured cadre activities, the impact on religious-related doctrines began to enter the minds of students. The concept of the struggle of the Prophet and the Companions of ra ajmain contained in the sirroh nabawiyah becomes the main reference, but is often used as a tool to lead opinions related to movements, Islamic struggles and the like. A legitimate government is equated with a thogut government, like King Pharaoh and King Namudz who do not obey religion so they have no obligation to obey government policies as long as the government does not obey Allah and His messenger.

The concept of study and Islamic cadre material at first only discussed matters of worship rituals, muamalah and muasyaroh in Islam. However, doctrines related to welfare inequality, the phenomenon of oppressed Islamic countries and the like can influence the mindset of a new student in college. The concept of struggle and the idea of their movement may still be at the stage of thought, but with the burning spirit of youth, the doctrine of Islamic struggle that they continue to lead can lead to certain actions. The actions in question are not just words, words and opinions in electronic media, they may escalate into physical actions that can harm others in the name of religion and the commandments of ALLAH.

By raising the enthusiasm of students through regular studies conducted by the cadres, their enthusiasm begins to burn. Comparing Islamic countries that are divided, warring, oppressed, becomes one of the most important material to look at their countries which have similarities in religious ideology and in terms of oppression. Injustice and also welfare are also one of the thought agenda in cadre activities. If the radical right students will be led to enforce Islamic law in terms of being a nation and state, towards the Khilafah Islamiyah, then radical left students will fight for the socialist understanding they profess which is also motivated by injustice and inequality in welfare so that justice is needed for all people through socialist marhaenism. . 
The pattern of inculcating radical student behavior starts from the spread of narrow fanaticism in understanding an event, life values and religious understanding. After that, an intensive approach is carried out through mentoring activities, or small groups, until they really believe and believe that what they are doing and their group is the most correct group, and consider other groups to be wrong or heretical or infidels. Only when this condition has been created, will the understanding and cultivation of radicalism begin to be incorporated and ultimately come to carry out a radicalism movement which in the end is the emergence of a terrorism movement. Finding 12. The spirit of Islam is used by radical cadres in Islamic activities on campus

Finding 13. Choose to be active in religious activities on campus with the spirit and feeling of playing an active role in upholding religion

Findings 14 . The content of the study was originally about muamalah and muasyaroh in Islam, but the doctrines that Islam is oppressed, Muslims are persecuted, and the like become the background of radical understanding that leads to radical actions.

Finding 15. The spirit of fighting for economic inequality is the reason for the struggle of both left and right radicals.

Minor Proposition 6. The concept of study and doctrine is channeled through routine activities, with topics related to inequality, people's suffering, and the like that have been able to arouse radical understanding of students in higher education.

The lack of supervision from the academic community on campus is one of the causes of the spread of nonacademic activities but without being associated with official organizations in the university environment. Preventive efforts are needed so that all student activities can be monitored properly at IHKAC. The rise of student movements with behavior that tends to be radical is also due to weak supervision from the campus. There is no supervisory system carried out by the campus, either as an activity supervisor or just a supervisor for the implementation of activities. All activities are handled entirely by students, so senior students are free to carry out activities according to their wishes.

There needs to be strict supervision from the university, so that the transfer of religious knowledge is indeed delivered by people who understand religion. If religious teachings are not delivered by those who understand religion, then religion will be delivered by people who only understand superficial Islam. Then relate the phenomena that occur in their environment in the context of the doctrine of political movements that are under the auspices of the Islamic religious movement. The campus must act, and take steps to structured preventive measures, starting from the level of Study Programs, Faculties and also Universities.

Finding 16. The lack of supervision from the campus related to religious and non-academic activities that can lead to the rise of radicalism

Finding 17. Supervision can be carried out in stages, starting from the level of study programs or departments, at the Faculty level, up to the Institute or University level.

Minor Proposition 7. Efforts are needed to increase supervision in stages for every activity in the university environment, starting from the level of study programs, faculties and institutes.

The results of interviews with several lecturers also showed some similar opinions regarding efforts to prevent radical behavior in universities. Once the teaching staff at universities, they think that there needs to be very strict supervision from the universities, so that the transfer of religious knowledge is indeed delivered by people who understand religion. Do not let religious teaching be delivered by those whose educational background is not religious education at all, worrying about distortion and misunderstanding. A religious teacher must understand religion so that religion will be conveyed by people who only understand Islam, have competence in the field of religion with all its scientific derivatives.

Regarding the phenomena that occur in the university environment, in the context of the doctrine of political movements in the name of the Islamic religious struggle, the campus must be firm, and take preventive steps that are structured, and earnest at every level in the university.

Because the $\mathrm{KH}$ Abdul Chalim Institute is a campus within a boarding school environment, it is appropriate that Islamic teaching activities be made part of the curriculum, such as studies on Ahlus Sunnah wal Jama'ah, nationality and love for the homeland. Universities must play an active role as a filter for the entry of radical ideas and behavior, so that the campus can be free from the tendency of ideas that can undermine the unity and integrity of the nation.

Finding 18. It is necessary to carry out strict supervision by the campus, especially related to religious and nonacademic activities that can lead to rampant radical behavior and understanding.

Finding 19. Islamic Religious Learning Materials can be included in the curriculum, because IkhaC is a campus in a pesantren environment.

Findings 20. Types of Islamic learning materials that can prevent the spread of radical understanding and behavior in universities, such as studies on ahlussunah wal congregation, nationality and love for the homeland.

Minor Proposition 8. Supervision of students on campus is not only carried out in stages for every activity in 
the university environment, but it is necessary to make deradicalization materials a curriculum on campus such as material on aswaja (ahlussunah wal congregation), nationality and love for the homeland.

Major Proposition 2. Students exposed to radicalism have a weak economic background, limited religious understanding, and desire to be active in socio-religious activities. There needs to be an effort to channel the desire to organize with strict supervision by the campus starting from the level of study programs or departments, faculty and institute levels.

\section{Thesis on Radicalism in Islamic Boarding Schools and Amanatul Ummah Islamic Boarding Schools}

Efforts to reduce the radical behavior of students in universities, in this case at the KH Abdul Chalim Institute, Amanatul Ummah Islamic Boarding School, Pacet, Mojokerto, East Java, turned out not to be a one or two day effort. In a study conducted on a group of college students using descriptive qualitative analysis showed surprising results. Regarding the results of qualitative descriptive analysis based on interviews with informants from the functionaries of the KH Abdul Chalim Institute, Amanatul Ummah Islamic Boarding School, several findings were obtained which then it can be concluded that radical symptoms and behavior among students of Amanatul Ummah Islamic Boarding School, Pacet, Mojokerto, East Java.

The radical behavior and understanding of students at IHKAC is principally influenced by external factors, because conceptually the curriculum, learning materials, non-academic activities, recruitment of teaching staff to tracking alumni, do not provide an opportunity for the development of radical understanding within the IHKAC campus. Students' radical understanding is triggered by several internal individual factors such as poverty or economic weakness, weak religious understanding, and social factors that the environment and society want to recognize. The external factors behind the symptoms of radicalism among students, the $\mathrm{KH}$ Abdul Chalim Institute, Amanatul Ummah Islamic Boarding School, Pacet, Mojokerto, East Java, turned out to be more influenced by structured studies conducted by lecturers from alumni and seniors, as well as involvement with other organizations. a student organization that in its studies often conveys and inserts certain doctrines and radical understandings with practical political nuances.

From the results of searches and research in the field, internal factors in the pesantren environment do not have a common thread in conveying radical understanding and behavior among students, especially in terms of the entry of radicalism in the Amanatul Ummah Islamic Boarding School environment. This is because the teacher recruitment process is very strict, coupled with the curriculum at the KH Abdul Chalim Institute which is indirectly affiliated with the ideology of struggle based on Ahlussunah wal Jama'ah, rahamatan lil alamin, has closed the gap for the possibility of spreading radicalism in the campus environment. either directly or indirectly.

The notion of radicalism among students at the $\mathrm{KH}$ Abdul Chalim Institute, which is allegedly going to enter through the door to the curriculum, learning methods, and extra-curricular activities, cannot be proven. So strict are the rules issued by Islamic boarding school caregivers and in this case is Prof. Dr. KH Asep Saifuddin Chalim, MA who really closed the gap in the entry of radicalism in the pesantren environment. Efforts to prevent radicalism through deradicalization efforts can be carried out through compulsory learning activities in the pesantren environment showing very positive and significant results.

In the end, referring to the findings and conclusions above, there are several suggestions that can be given through this paper, especially in minimizing the understanding of radicalism in the pesantren environment, including;

1. Learning methods and curriculum in tertiary institutions should always be controlled so that they do not become the entrance to radicalism in the pesantren environment, especially at the $\mathrm{KH}$ Abdul Chalim Institute.

2. The method of recruiting ustadz and lecturers, not only using the parameters of teacher competence, but the values of Ahlussunah wal Jama'ah are expected to minimize radicalism in the pesantren environment.

3. Non-academic learning (extra curricular) needs to be guided, so as not to get out of the vision and mission of the Islamic boarding school. This is important because one of the entrances for radicalism is teachers from outside the pesantren who can enter through non-academic or extra-curricular activities.

4. The target of graduates from institutions can be a trigger so that every institution in the pesantren focuses on its achievement targets.

5. Tracking the whereabouts of graduates needs to be done so that between pesantren and alumni still have closeness in administrative data and are easy to monitor.

6. The participation of alumni in pesantren can be one of the pesantren's efforts to restore the ideals of the pesantren to its alumni. With service activities, it is hoped that alumni students can continue to stay in touch with the pesantren.

7. Radical understanding and behavior in the university environment is dominated by the entry of new students in higher education. There needs to be stricter procedures so that this can be prevented from the start, even before they enter the pesantren environment.

8. Integrated and continuous control is very much needed by universities, so that every activity will be monitored 
properly and accompanying lecturers can report on student activities regularly.

\section{BIBLIOGRAPHY}

Abdusshomad, M. (1993). Etika Bergaul. Bandung: Diponegoro

Abdullah, Taufik (ed). (1988). Tesis Weber dan Islam di Indonesia dalam Agama, dalam Etos Kerja dan Perkembangan Ekonomi, cet. IV. Jakarta: LP3ES

Abdulsyani (1994). Sosiologi Sekmatika, Teori, dan Terapan. Jakarta: Bumi Aksara.

Akh Fauzi, Aseri, Bayani Dahlan, Mariatul Asiah. (2015). Radikalisme Islam di Kalangan Mahasiswa Perguruan Tinggi Negeri di Banjarmasin. Jurnal Tashwir, Volume 3, Nomor 6, pp. 175-197

Alfred, John dan James Julian M. (2008). Belajar Kepribadian. The Accelerated Learning for Personality. Yogyakarta : BACA!.

Ayub Mursalin, Ibnu Katsir (2010). Pola Pendidikan Keagamaan Pesantren dan Radikalisme: Studi Kasus Pesantren-pesantren di Provinsi Jambi., Kontekstualita, Vol. 25, No. 2, 2010, Halaman 255-290

Azhari, Akyas. (2004). Psikologi Umum dan Perkembangan. Jakarta Selatan: Penerbit Teraju

Ali, Lukman (1996). Kamus Besar Bahasa Indonesia, Edisi Kedua, Cetakan Ketujuh. Jakarta: Balai Pustaka

Ancok, Djamaludin. (2008). Ketidakadilan sebagai Sumber Radikalisme dalam Agama: Suatu Analisis Berbasis Teori Keadilan dalam Pendekatan Psikologi. Jurnal Psikologi Indonesia, Nomor 1, pp. 1-8

Andresky, Stanislav. (1989). Max Weber: Kapitalisme, Birokrasi dan Agama. Yogyakarta: Tiara Wacana

Armstrong, Kareen. (2001). Berperang Demi Tuhan, Fundamentalisme dalam Islam, Kristen dan Yahudi. Jakarta: Serambi

Bergson, H., Mullarkey, John (2007) An Introduction to Metaphysics, Palgrave Macmillan

Baron, R.A. dan Byrne, D. (2005). Psikologi sosial. Edisi kesepuluh: jilid 2. Jakarta: Erlangga.

Berger, Peter L dan Thomas Luckman. (1991). Langit Suci: Agama sebagai Realitas Sosial. Jakarta: LP3ES

Berger, L. Peter dan Luckmann, Thomas. (1966). The Social Construction of Reality. Unites States: Anchor Book.

Bimo, Walgito, (2004). Pengantar Psikologi Umum, Andi, Jakarta

Braudel, Fernand. (1996). The Mediterranean and The Mediterranean World in the Age of Philip. California: University of California Press

Bungin, Burhan. (2008). Penelitian Kualitatif, Jakarta: Kencana Prenada Media Group

Debora Sanur L. (2016). Upaya Penanggulangan Terorisme ISIS di Indonesia. Politica, Volume 7, Nomor 1, pp. $25-47$

Deliar Noer (1983), Pengantar ke pemikiran politik. Jakarta : Rajawali

Derrida, Jacques. (2002). Acts of Religion. Ed. Gil Anidjar. New York: Routledge Press

Deswita. (2006). Psikologi Perkembangan. Bandung: Remaja Rosdakarya.

Dhofir, Zamarkahsyari. (1982). Tradisi Pesantren: Studi tentang Pandangan Hidup Kyai. Jakarta: LP3ES

Durkheim, Emile (1982). The Rules of Sociological Method. Edisi Pertama. Halls, New York: The Free Press.

Emna Laisa. (2014). Islam dan Radikalisme. Jurnal Islamuna, Volume 1, Nomor 1

Fritz Heider (1983), The Psychology of Interpersonal Relations, Publons: Psychology Press

Foucault, Michel. (2002). Arkeologi Pengetahuan. (Terjemahan oleh H.M. Mochtar Zoerni). Yogyakarta: Qalam

Ganor, Boaz. (2002). Defining Terrorism: Is One Man's Terrorist Another Man's Freedom Fighter?. Media Asia Communication Quarterly, Volume 20, Nomor 3, pp. 128-129

Geertz, Cliffort. (1989). Abangan, Siswa, Priyayi dalam Masyarakat Jawa. Jakarta: Pustaka Jaya

Gerungan, W. A (1986). Psikologii Sosial., Bandung. PT Refika Aditama

Hilmy, Masdar. (2015). Radikalisme Agama dan Politik Demokrasi di Indonesia Pasca-Orde Baru. Jurnal Miqot, Volume XXXIX, Nomor 2, pp. 407-425

Huberman A. Michael, Matthew. B Milles, dan Johnny Saldana. (2014). Analisis Data Kualitatif. Jakarta: Universitas Indonesia Press

Ibrahim, Saad M. (1997). Kemiskinan dalam Perspektif Al-Qur'an. Disertasi. Jakarta: Pasca Sarjana, Institut Agama Islam Negeri Syarif Hidayatullah

Ibrahim, Rusli (2001). Promosi Kesehatan Dengan Pendekatan Teori Perilaku Media dan Aplikasinya. Semarang., PT Raja Grafindo Persada.

J.S Furnivall, (2014). Colonial policy and practice: a comparative study of Burma and Netherlands India., Cambridge: Cambridge University Press

Jalaludin Rakhmat, (2008). Psikologi Komunikasi. Bandung: PT. Remaja Rosdakarya

James. M. Henslin. (1990). Social Problems, Prentice Hall, Second Edition. New Jersey: Englewood Cliffs

John Loftland. (2007). Handbook of Ethnography. eds P Atkinson, A Coffey, S Delamont, L Loftland. London: Sage Publications

Jones, Pip (2009), Pengantar Teori-teori Sosial Dari Teori Fungsionalisme Hingga Post Modernisme, Jakarta: Pustaka Obor 
Jones, Sidney. (2015). Sisi Gelap Demokrasi Kekerasan Masyarakat Madani di Indonesia. Jakarta: Yayasan Paramadina

Kaelani, HD (2000). Islam Dan Aspek-Aspek Kemasyarakatan. Jakarta: Bumi Aksara.

Krech, Crutchfield dan Ballachey (1982). Individual in Society. Tokyo: Mc Graw-Hill International Book Company.

Kirsten E. Schulze dan Joseph Chinyong Liow. (2018). Making Jihadis, Waging Jihad: Transnational and local dimensions of the ISIS phenomenon in Indonesia and Malaysia. Asian Security, pp. 122-139

Kirsten E. Schulze. (2018). The Surabaya Bombings and the Evolution of the Jihadi Threat in Indonesia. Combating Terorism Center at West Point, Volume 11, Nomor 6, pp. 1-6

Lawrence Erlbaum (1989). Associates, Text Book of Psichology, Hillsdale New Jersey

Le Roy Ladurie, Emmanuel \& Joseph Goy. (2008). Tithe and Agrarian History from the Fourteenth to the Nineteenth Centuries. Paris: Cambridge University Press

Levi-Strauss C. (1966). The Science of the Concrete in The Savage Mind. London: Weidenfeld \& Nicolson

Lewin, K. (1951). Field theory in social science: selected theoretical papers (Edited by Dorwin Cartwright.). Harpers.

Lexy J. Moleong. (2009). Metodologi Penelitian Kualitatif. Bandung: Remaja Rosdakarya

Mantja, W. (2003). Etnografi Disain Penelitian Kualitatif dan Manajemen Pendidikan. Malang: Winaka Medi

Mar'at (1981) Sikap Manusia Perubahan dan Pengukurannya. Jakarta: Ghalia Indonesia

Marx, Karl. (1982). Towards a Critique of Hegel's Philosophy of Right. London: Cambridge University Press

Maslow, Abraham (1970). Motivation and Personality. New York: Harper \& Row Publisher.

Mauhibur Rokhman, Asep Saefuddin Chalim, Agus Sholahuddin, Dwi Suharnoko, Fadly Usman. (2020). Geospatial of Terrorism and Radicalism in Indonesia -A Preventive Efforts-. IOSR Journal of Humanities And Social Science, Volume 25, Nomor 7, pp. 01-09

Muhammad Haidar Assad. (2016). ISIS: Organisasi Teroris Paling Mengerikan Abad Ini. Zahira

Muhammad Reno. (2014). ISIS Kebiadaban Konspirasi Global. Jakarta: Noura Books

Muhibbin Syah (2000), Psikologi Pendidikan dengan Pendekatan Baru, Edisi Revisi, Cetakan V, Bandung: Remaja Rosdakarya

Muladi (2004). Penanggulangan Terorisme sebagai Tindak Pidana Khusus. Seminar Pengamanan Terorisme sebagai Tindak Pidana Khusus, Jakarta, 28 Januari 2004

Nawawi, Hadari. (1993). Metode Penelitian Sosial. Yogyakarta: Gajah Mada University Press

Novan Ardy Wiyani. (2013). Pendidikan Agama Islam Berbasis Anti Terorisme di SMA. Jurnal Pendidikan Islam, Volume II, Nomor 1

Nunung Prajarto. (2004). Terorisme dan Media Massa: Debat Keterlibatan Media. Jurnal Ilmu Sosial dan Ilmu Politik, Volume 8, No L

Nurjannah. (2013). Faktor Pemicu Munculnya Radikalisme Islam Atas Nama Dakwah. Jurnal Dakwah, Volume XIV, Nomor 2

Peter L. dan Luckman, Thomas. (1991). Tafsir Sosial atas Kenyataan: Risalah tentang Sosiologi Pengetahuan. Jakarta: LP3ES

Priyono, B Herry (2002). Anthony Giddens: Suatu Pengantar, Jakarta: Kepustakaan Populer Gramedia

Qardawi, Yusuf. (2002). Teologi Kemiskinan: Doktrin Dasar dan Solusi Islam atas Problem Kemiskinan. Yogyakarta: Mitra Pustaka

Ridlwan, Mujib. (2013). Revitalisasi Peran Profetik Pesantren dalam Membendung Radikalisme Agama. Jurnal Al Hikmah, Volume 3, Nomor 1, pp. 25-36

Ritzer, George dan Douglas J. Goodman. (2008). Teori Sosiologi Modern. Terjemahan: Alimandan. Jakarta: Kencana Prenada Media Group

Robert K. Merton. (1967). On Theoritic al Sociology. New York: The Pree Pres

Raho, Bernard. (2007). Teori Sosiologi Modern, Jakarta: Prestasi Pustaka Publisher

Sa'dulloh Muzammil. (2015). Upaya Pencegahan Radikalisme Agama dan Terorisme melalui Pemilihan Tema Bahan Ajar pada Mata Kuliah English For Islamic Studies. Jurnal At-Turats, Volume 9, Nomor 1

Saleh, Abdul Rahman (2009). Psikologi; Suatu Pengantar Dalam Perspektif Islam, Jakarta: Kencana

Saleh, Muwafik A (2012) Psikologi Perkembangan, Jakarta: Rineka Cipta

Saifuddin (2011). Radikalisme Islam di Kalangan Mahasiswa (Sebuah Metamorfosa Baru). Analisis, Volume XI, pp. $17-32$

Soenarjo, dkk. (1989). Al-Qur'an dan Terjemahnya, Semarang: CV. Toha Putra.

Soetandyo Wignjosoebroto (2002). Hukum (Paradigma, Metode dan Dinamika Masalahnya), Jakarta: ELSAM dan HUMA

Sukanda Sadeli (2012). Bimbingan Akhlak Yang Mulia. Jakarta: Yayasan Pendidikan Islam Amal Soleh

Suprapto. (2018). Aksi Terorisme: Dari Gerakan Ideologis Ke Gerakan Inkonstitusional. Casarjana Sosiologi Universitas, Volume 12, Nomor 2 
Taufiq, Muhammad Izzuddin. (2006). Panduan lengkap dan praktis psikologi Islam Cetakan I. Jakarta: Gema Insani Press.

Turner, Bryan S. (2006). Runtuhnya Universalitas Sosiologi Barat: Bongkar Wacana atas Islam vis a vis Barat, Orientalisme, Postmodernisme dan Globalisme. Yogyakarta: Ar Ruz

Umar, Ahmad Rizky Mardhatillah. (2010). Melacak Akar Radikalisme di Indonesia. Jurnal Ilmu Sosial dan Ilmu Politik, Volume 14, Nomor 2, pp. 171-172

Undang-undang tentang Penetapan Peraturan Pemerintah Pengganti Undang-Undang Nomor 1 Tahun 2002 tentang Pemberantasan Tindak Pidana Terorisme

Weber, Max. (2000). Etika Protestan dan Semangat Kapitalisme. Surabaya: Promothea

William J. Goode dan Paul K. Hatt. (1981). Methods in Social Research. Kogakusa: McGraw-Hill Book Company

Zaini Dahlan, dkk, (1995). Al-Qur'an dan Tafsirnya, Yogyakarta, PT. Dana Bhakti Wakaf, Universitas Islam Indonesia

Zimmerman dan Schank (2013)., Educational Psychology. Prentice Hall, New York, Second Edition.

Zumri Bestado Sjamsuar. (1999). Paradoks Pikiran Keagamaan: Kritik terhadap Pereduksian Simbol Agama. Suara Almamater Publikasi Ilmiah Universitas Tanjungpura, Volume XIV, Nomor 6

\section{Internet:}

http://dreamsnmotion.com/word-of-the-day/2015/12/19/radicalize (diakses 22 Juli 2020)

http://www.merdeka.com/peristiwa/berapa-jumlah-annggota-dan-kekuatan-isis-diIndonesia.html. (diakses 17 Juni 2020)

http://www.rappler.com/indonesia/119355-dendam-jaringan-teroris-santoso-kepada-polisi (diakses 21 Juli 2020)

http://www.republika.co.id/berita/dunia-islam/islamnusantara/09/02/06/29871-perlu-deradikalisasi-pemahamanislam-diponpes. (diakses 17 Juni 2020) 